\title{
On-target deposit and vertical distribution of aerially released herbicides
}

\author{
by Dean G. Thompson ${ }^{1}$, Douglas G. Pitt ${ }^{1}$, Bozena Staznik ${ }^{1}$, Nicholas J. Payne ${ }^{1}$, David \\ Jaipersaid $^{1}$, R.A. Lautenschlager ${ }^{2}$ and F. Wayne Bell ${ }^{2}$
}

As a component of the Fallingsnow Ecosystem Project, glyphosate and triclopyr herbicides (Vision ${ }^{\circledR}$, Release $^{\circledR}$ ) were each applied to four experimental spray plots at nominal rates of 1.5 and $1.9 \mathrm{~kg}$ a.e. $\mathrm{ha}^{-1}$ respectively. Empirical studies were undertaken on these plots with the objectives of; a) quantifying mean on-target deposit and variability b) assessing the vertical distribution of active ingredient deposits through the vegetative complex and c) comparing herbicide deposit estimates on excised natural foliage with those on proximal 2-dimensional (2D) and 3-dimensional (3D) collectors. Experimental conditions were representative of difficult aerial application scenarios since the spray plots were small ( 4.9 to $10.4 \mathrm{ha}$ ), with irregular boundaries of mature timber, and in some cases substantial topographical relief. Deposit analysis confirmed that, in some circumstances, locations well within target areas were missed completely owing to inappropriate track spacing or swath offset. Excluding these points from the data analysis, results demonstrated overall mean deposition (mean $\pm \mathrm{SE}$ ) of glyphosate and triclopyr on aspen foliage equating to $68.45 \pm 6.13$ and $50.28 \pm 6.01 \%$ of the nominal application rates (1.5 and $\left.1.9 \mathrm{~kg} \mathrm{ha}^{-1}\right)$, respectively. A high degree of variation in deposit both within and between plots demonstrate that variation in operational parameters (e.g. track spacing, offset, release height and aircraft speed) as influenced by local site factors (e.g. proximity of standing timber, topographical relief) can be important determinants in uniformity and accuracy of herbicide deposit. A consistent trend $(P<0.001)$ in the deposition profile through tiered vegetative canopies was observed, with greatest impingement of the spray in the upper target canopy as noted above, and average $25 \%$ and $12 \%$ in the shrub and ground-level tiers respectively. Results suggest that for sites characterized by complex canopies, differential vertical deposition may be an important factor constraining the potential use of lower herbicide application rates, particularly where shrub or groundcover species are important competitors. In contrast, given that only a small proportion of the spray cloud penetrates and impinges in the lower vegetative tiers, animals foraging or living therein may receive substantially reduced exposures, mitigating against any potential direct effects. In general, poor correlations ( $r=0.22$ to 0.78$)$ in deposit estimates based on either two-dimensional or threedimensional artificial collectors as compared to excised natural foliage were observed. Significant differences $(P<0.05)$ also were detected among deposit estimates with no consistent trend in relation to herbicide treatment, sampler type or sampling height. These comparisons suggest that none of the artificial collector types tested accurately or consistently estimated true foliar deposit.

Key words: alternative conifer release treatments, Fallingsnow Ecosystem Project, glyphosate, herbicides, herbicide deposit, tending, triclopyr, vegetation management, vertical distribution

${ }^{1}$ Canadian Forest Service, 1219 Queen St. E., Sault Ste. Marie, Ontario, Canada P6A 5M7.

${ }^{2}$ Ontario Ministry of Natural Resources, Ontario Forest Research Institute, 1235 Queen St. E., Sault Ste Marie, Ontario, Canada P6A 5N5.
Au cours du projet écosystémique de Fallingsnow, les phytocides glyphosate et triclopyr (Vision ${ }^{\circledR}$, Release ${ }^{\circledR}$ ) ont été pulvérisés sur quatre parcelles d'essai de pulvérisation selon des taux nominaux de 1.5 et de $1.9 \mathrm{~kg}$ é.a. $\mathrm{ha}^{-1}$ respectivement. Des études empiriques furent entreprises sur ces parcelles dans le but de: a) quantifier le dépôt moyen sur la cible et sa variabilité; b) d'évaluer la distribution verticale de l'ingrédient actif des dépôts au travers du complexe végétatif; et c) comparer les estimés de dépôt de phytocide sur du feuillage naturel récolté par rapport aux collecteurs d'échantillons selon 2 et 3 dimensions situés à proximité. Les conditions expérimentales étaient comparables aux scénarios de pulvérisation sous conditions difficiles puisque les parcelles d'essai étaient petites ( 4.9 à 10.4 ha), localisées entre des peuplements de bois à maturité ayant des limites irrégulières, et dans certains cas situées dans un contexte topographique difficile. L'analyse des dépôts a confirmé dans certaines circonstances que des points situés clairement à l'intérieur des cibles ont été complètement manqués suite à un espacement inadéquat des rampes et de l'effet de déviation. Une fois ces points exclus de l'analyse des données, les résultats ont démontré un dépôt global moyen (moyenne \pm é.t.) du glyphosate et du triclopyr sur le feuillage de peuplier équivalent à $68.45 \pm 6.13$ et $50.28 \pm 6.01 \%$ des taux nominaux d'application ( 1.5 et $1.9 \mathrm{~kg} \mathrm{ha}^{-1}$ ) respectivement. Un niveau de variation des dépôts à la fois dans les parcelles et entre les parcelles démontre que les changements dans les paramètres opérationnels (i.e., l'espacement entre les rampes, déviation, hauteur de pulvérisation et vitesse de l'appareil) tel qu'influencés par les facteurs locaux du site (i.e. proximité des peuplements vivants, relief topographique) peuvent avoir une influence déterminante sur l'uniformité et la précision des dépôts de phytocide. Une tendance constante $(P<0.001)$ dans le profil des dépôts a été observée parmi les trois tiers de la couverture végétale, la plus forte proportion de la pulvérisation se retrouvant sur le tiers supérieur de la couverture ciblée, et une moyenne de $25 \%$ et de $12 \%$ sur le tiers arbustif et herbacé respectivement. Les résultats laissent entendre que pour les sites identifiés comme ayant une couverture végétale complexze, le différentiel vertical du dépôt peut constituer un facteur important exercant une contrainte sur l'utilisation potentielle de taux plus faibles de phytocides, particulièrement lorsque les arbustes et les végétaux au sol sont d 'importants compétiteurs. Cependant, étant donné que seulement une faible proportion des pulvérisations pénètrent et recouvrent le tiers inférieur de la végétation, les animaux broutant ou vivant dans ce tiers seraient substantiellement moins exposés, le tout réduisant les effets potentiels directs. De façon générale, on a observé que de faibles corrélations $(r=0.22$ à 0.78$)$ parmi les estimés des dépôts établis selon les collecteurs artificielles en deux et trois dimensions lorsque comparés au feuillage naturel recueilli sur place. Des différences significatives $(P<0.05)$ ont été également notées au sein dos estimés de dépôt sans pouvoir établir de tendance constante en relation avec le traitement phytocide, le type d'échantillon et la hauteur d'échantillonnage. Ces comparaisons laissent entendre qu'aucun des collecteurs artificiels testés avec précision ou de façon constante n'a permis d'estimer avec précision le dépôt sur les feuilles.

Mots clés: traitements alternatifs de dégagement des conifères, projet écosystémique de Fallingsnow, glyphosate, phytocides, dépôt de phytocide, soins culturaux, triclopyr, contrôle de la végétation, distribution verticale.

\section{Introduction}

While many physical, chemical and biological variables may affect the efficacy of a herbicide treatment, all do so through 
some influence on the fundamental dose-response relationship. In the case of foliar-applied herbicides, effectiveness depends to a large degree on the quantity of active ingredient impinging on target foliage, as well as the size-distribution and coverage of the depositing droplets. Given a constant nominal application rate and drop-size spectra at release, the quantity and quality of deposit are in turn controlled by a variety of operational and meteorological variables. Based on parametric sensitivity analyses for the FSCBG spray model (Teske and Barry 1993), the most important of these are release height, spraying speed, wind direction and wind speed. Picot et al. (1993) provide empirical data which also suggest that release height is a critical factor controlling deposit and off-target drift of aerially applied insecticides.

While quantification of on-target deposit in these terms is critical to fully understanding efficacy or assessing potential non-target effects, accurate estimation under operational conditions is difficult, expensive and time-consuming. Historically, coverage and drop-size spectra of aerially released pesticides have been assessed using indirect methods involving dyed spray mixtures and Kromekote cards or other collection surfaces, even though this approach is fraught with a number of difficulties and potential extrapolative errors (Teske et al. 1994; Duan et al. 1994). Deposit of active ingredients may involve similar indirect methods or direct quantification of active ingredient on the target foliage or a simulant thereof (Riley et al. 1991; Thompson et al. 1992; Payne and Thompson 1992; Richardson et al. 1989, 1990; Payne 1993). In cases where artificial collection surfaces were used, the influence of differential surface characteristics and geometry as these affect impingement of the spray cloud, has been recognized. Numerous workers have promoted the use of three-dimensional (3D) collectors (Richardson et al. 1989; Miller et al. 1992; Duan et al. 1994). The advantage of $3 \mathrm{D}$ collectors is believed to be related to enhanced sampling efficiency for small droplets which may follow non-linear, often swirling trajectories (Carleton and Bouse 1987) and reduced correlation of sampling efficiency with wind-speed (Duan et al 1994). Given all of these considerations, direct quantification of the active ingredient on the critical target foliage, which involves the least number of assumptions and extrapolations, is a preferred approach to estimating actual on-target deposit.

Several field studies quantifying on- or off-target deposit of herbicides under conditions pertinent to Canadian forest regeneration practices have been published elsewhere (Payne et al. 1990; Riley et al. 1991; Payne and Thompson 1992; Thompson et al. 1992; Newton et al. 1990; Payne 1993). Experimental conditions for some of these studies involved essentially flat terrain, large spray blocks ( $>50 \mathrm{ha})$ and/or relatively simple vegetative canopy structures which may be associated with herbicide applications to large clearcuts. In recent years, silvicultural practices have been conducted more frequently on smaller clearcuts bounded by relatively mature standing timber, resulting in aerial application scenarios which differ markedly from those associated with the existing experimental database. As a component of a multi-disciplinary research effort referred to as the "Fallingsnow Ecosystem Project" (Lautenschlager et al. 1997), this study was conducted to provide chemical accountability data pertinent to aerial applications of glyphosate (Vision ${ }^{\circledR 3}$ ) and triclopyr ester (Release ${ }^{\circledR 4}$ )

\footnotetext{
${ }^{3}$ Trademark of Monsanto.

${ }^{4}$ Trademark of DowElanco.
}

herbicides under difficult operational spray scenarios inclusive of small spray block sizes, proximity of standing timber, and substantial topographical relief. The objectives of the study were to:

a) quantify mean on-target deposit and variability under difficult operational spray scenarios

b) determine the vertical distribution of foliar deposit through the vegetative complex and

c) compare deposit measured on excised natural foliage with those on 2D and 3D artificial collectors.

These objectives relate, directly or indirectly, to a number of priorities for forestry herbicide application technology research (Campbell and Howard 1993).

\section{Methods}

\section{Site Description and Preparation}

A detailed description of the Fallingsnow Ecosystem Project and experimental site is provided in preceding papers (Lautenschlager 1997; Bell et al. 1997). Briefly, the overall experiment comprised four blocks of varying size ( 28 to 52 ha), proximally located (within $6.6 \mathrm{~km}$ of one-another) on sites typical of the Great Lakes-St. Lawrence forest region in northwest Ontario. All blocks were classified as aspen-spruce-mixedwoods under the forest resource inventory, had been harvested three to eight years prior to initiation of this experiment, and replanted with bareroot spruce stock. In all cases, the blocks had become dominated by a tiered complex of competing vegetation comprised predominantly of trembling aspen (Populus tremuloides Michx.) (12.3\% cover, $2.5 \mathrm{~m}$ height), red raspberry (Rubus idaeus $\mathrm{L}$. var. strigosus [Michx.] Maxim) ( $9.6 \%$ cover, $0.6 \mathrm{~m}$ height) and graminaceous/herbaceous groundcover $(5 / 38 \%$ cover, $0.5 / 0.3$ $\mathrm{m}$ height) (Bell et al. 1997). Each block was divided into five smaller plots which were randomly assigned to one of five alternative conifer release treatments:

1) motor-manual (brush saw)

2) mechanical (Silvana Selective/Ford Versatile)

3) aerial Release ${ }^{\circledR}$ herbicide (triclopyr @ $1.9 \mathrm{~kg}$ a.e. $\mathrm{ha}^{-1}$ )

4) aerial Vision ${ }^{\circledR}$ herbicide (glyphosate @ $1.5 \mathrm{~kg} \mathrm{a.e.} \mathrm{ha}{ }^{-1}$ ) and

5) control (no treatment).

For the purposes of this paper, only the herbicide treatment plots will be considered in detail. Herbicide treatment plots ranged from 4.9 to 10.4 ha in size and varied in shape, proximity to mature trees ( $23 \mathrm{~m}$ height) and geographic orientation relative to other treatment plots and to flight direction during herbicide applications (Fig. 1, Table 1).

One week prior to treatment, the mean and 95 th percentile range of leaf-area-index (LAI) for all plots was determined by monitoring the incident radiation at $3.5 \mathrm{~m}$ (one reading above the aspen canopy) and radiation penetrating the aspen canopy (six readings at $1.0 \mathrm{~m}$ height within a $1 \mathrm{~m}^{2}$ area) on a systematic $60 \mathrm{~m}$ grid. LAI measurements were made with a LI-COR ${ }^{\circledR}$ LAI-2000 (LI-COR Inc. Lincoln, Nebraska) plant canopy analyzer, equipped with a single LAI-2050 sensor fitted with a 270 degree view cap, following the manufacturers' suggested protocol (LI-COR 1991). Under this protocol, the effective range of view for the readings was calculated by the following equation:

$$
A=f \times \pm \times h^{2}
$$




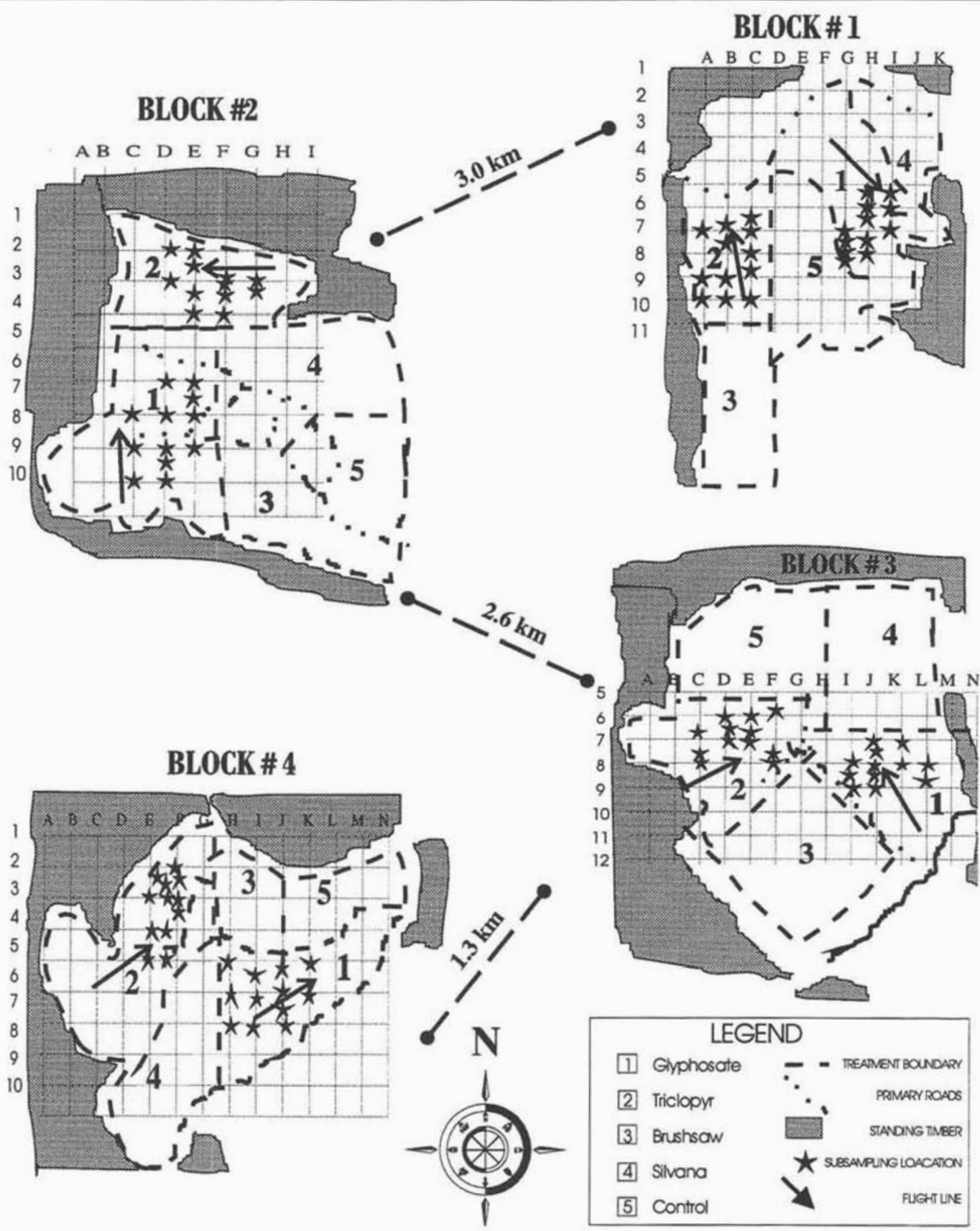

Fig. 1. Schematic representation of herbicide spray plots showing sub-sampling locations with respect to standing timber and flight lines.

where $A=$ ground area represented by the sample, $f=$ view fraction $(0.75)$ correction for view cap, and $h=$ canopy height in meters (3.0).

Based on this calculation, the LAI measurements integrate light penetration over an area of $21 \mathrm{~m}^{2}$.

The initial LAI readings were used to establish 12 sub-sampling (SS) locations along $60 \mathrm{~m}$ transect lines within the inner $120 \times 180 \mathrm{~m}$ portion of each of the treatment plots (Fig. 1). Sub-sampling positions were chosen such that six of the selected points were representative of the overall mean for all plots $(0.65)$ and the six remaining positions spanned the 95 th percentile range of LAI values for all blocks (i.e. at points where $\mathrm{LAI}=<0.1,0.2,0.4,0.9,1.2$, and 1.5).
At each of the designated subsampling locations, an array of artificial and natural collectors were installed at heights of $3.5 \mathrm{~m}$ (above the aspen canopy), $1.0 \mathrm{~m}$ (above the raspberry canopy) and $0.5 \mathrm{~m}$ (above the ground-cover layer) (Fig. 2). Each collector array was comprised of an excised natural leaf (aspen at $3.5 \mathrm{~m}$, raspberry at $1.0 \mathrm{~m}$ and a $10 \mathrm{~cm}$ segment of grass blade at $0.5 \mathrm{~m}$ ), a 2-dimensional (2D) collector, a 3-dimensional (3D) collector and a Kromekote card to allow assessment of drop-size spectra for the impinging fraction of the spray cloud. The mean $( \pm \mathrm{SD})$ silhouette area of natural aspen (19 $\left.\pm 4 \mathrm{~cm}^{2} ; n=50\right)$, raspberry $\left(20 \pm 6 \mathrm{~cm}^{2} ; n=50\right)$ and $10 \mathrm{~cm}$ grass ( $4.4 \pm 0.7 \mathrm{~cm}^{2} ; n=1$ to 10 ) foliage was determined using video image analysis (Artek Model 982, Farmington, New York). 


\begin{tabular}{|c|c|c|c|c|}
\hline Characteristic & Plot 1 & Plot 2 & Plot 3 & Plot 4 \\
\hline Longitude (west) & $89^{\circ} 49^{\prime}$ & $89^{\circ} 49^{\prime}$ & $89^{\circ} 50^{\prime}$ & $48^{\circ} 0^{\prime}$ \\
\hline \multicolumn{5}{|c|}{ Nominal (actual) plot size (ha) } \\
\hline Glyphosate & $9.9(7.6)$ & $6.5(5.5)$ & $10.4(7.1)$ & $5.3(3.6)$ \\
\hline Triclopyr & $4.9(3.9)$ & $6.5(3.7)$ & $8.1(6.6)$ & $9.3(7.4)$ \\
\hline \multicolumn{5}{|c|}{ Mix volume applied (L) } \\
\hline Glyphosate & 310 & 202 & 286 & 141 \\
\hline Triclopyr & 198 & 184 & 209 & 260 \\
\hline \multicolumn{5}{|c|}{ Calculated rate $\left(\mathrm{kg}\right.$ a.e. $\left.\mathrm{ha}^{-1}\right)$} \\
\hline Glyphosate & 1.79 & 1.62 & 1.77 & 1.72 \\
\hline Triclopyr & 2.84 & 2.78 & 1.77 & 1.97 \\
\hline \multicolumn{5}{|l|}{ Treatment time } \\
\hline Glyphosate & $7: 22-7: 41$ & $7: 45-7: 56$ & $6: 55-7: 06$ & $7: 11-7: 18$ \\
\hline Triclopyr & $9: 20-9: 30$ & $21: 03-21: 10$ & $21: 14-21: 25$ & $9: 34-9: 45$ \\
\hline \multicolumn{5}{|c|}{ Flight line (azimuth) } \\
\hline Glyphosate & 145 & 003 & 338 & 58 \\
\hline Triclopyr & 358 & 280 & 243 & 214 \\
\hline \multicolumn{5}{|c|}{ Wind speed $\mathrm{m} \mathrm{s}^{-1}$ (@18.5 m a.g.1.) } \\
\hline Glyphosate & 0.9 & 1.0 & 1.9 & 1.5 \\
\hline Triclopyr & & 2.7 & 2.8 & \\
\hline \multicolumn{5}{|c|}{ Wind direction (azimuth@18.5 m) } \\
\hline Glyphosate & 291 & 268 & 299 & 289 \\
\hline Triclopyr & & 320 & 313 & \\
\hline \multicolumn{5}{|c|}{ Air temperature (ํㅇ $@ 18.5 \mathrm{~m})$} \\
\hline Glyphosate & 12.8 & 13.0 & 13.1 & 13.2 \\
\hline Triclopyr & & 15.3 & 15.1 & \\
\hline \multicolumn{5}{|c|}{ Relative humidity (\%@18.5 m) } \\
\hline Glyphosate & 98 & 98 & 98 & 98 \\
\hline Triclopyr & & 89 & 89 & \\
\hline
\end{tabular}

Notes: Mix concentrations were: $123.5 \mathrm{~L}$ Vision $\$ 1000 \mathrm{~L}$ total $=0.044 \mathrm{~kg}$ a.e L $\mathrm{L}^{-1}$ and $105 \mathrm{~L}$ Release ${ }^{\otimes} / 900 \mathrm{~L}$ total $=0.056 \mathrm{~kg}$ a.e. $\mathrm{L}^{-1}$.

Calculated rate $=\operatorname{mix}$ volume applied $(\mathrm{L}) \times \operatorname{mix}$ concentration $\left(\mathrm{kg}\right.$ a.e. $\left.\mathrm{L}^{-1}\right) /$ actual treatment area $(\mathrm{ha})$

Data for triclopyr plots one and four unavailable due to equipment malfunction.

Boundary layer stable for all plots in both treatments.

For sampling at the 3.5 and $1.0 \mathrm{~m}$ levels, Whatman \#1 glass fibre filter paper (surface area $38.48 \mathrm{~cm}^{2}$ ) and a small Teflon ball (surface area $45.34 \mathrm{~cm}^{2}$ ) were used as 2D and 3D collectors, respectively. Based on preliminary spray chamber results, the expected and realized drop-size spectra, and our subsequent field observations which showed essentially no deposition to the lower half of Teflon balls, deposit for these collectors were calculated based on the assumption of active-ingredient deposition primarily through vertical mass flux (Duan et al. 1994) and using only half of the total surface area (i.e. $22.67 \mathrm{~cm}^{2}$ ). At the groundcover sampling level, a Teflon microtube (3D surface area $5 \mathrm{~cm}^{2}$ ) and a Teflon strip (2D surface area $5 \mathrm{~cm}^{2}$ ) were used to simulate grass blades and a Teflon ball was included to provide cross-comparison of deposit at the 1.0 and 3.0 $\mathrm{m}$ sampling height.

To minimize effects of sampler interaction, all collectors were affixed to small gauge copper wire frames using small aligator clips arranged at $90^{\circ}$ separation angles. Wire frames were attached to hinged $2.54 \times 5.08 \mathrm{~cm}$ aluminium or wooden stakes, such that the sampler array was $\sim 0.3 \mathrm{~m}$ above the stake and at the appropriate height above ground $(3.5 \mathrm{~m}, 1.0 \mathrm{~m}$, and 0.5 $\mathrm{m})$. Stakes were guyed with nylon rope to ensure that the sampler remained perpendicular to the ground surface. On the day prior to application, all collectors with the exception of natural foliage, were installed and covered with plastic bags to protect against dew. Immediately prior to chemical application (i.e. within $1.5 \mathrm{~h}$ ), plastic covers were removed, excised natural foliage from surrounding vegetation was installed, and collector arrays were raised to the appropriate sampling height and tied.

\section{Meteorological Monitoring}

Meteorological stations established immediately adjacent to blocks one, two and three were used to monitor wind speed and direction, air temperature, and relative humidity during the spray periods (approx. $10 \mathrm{~min}$ for each plot). Given the proximal location of blocks three and four (Fig. 1) the main meteorological station located adjacent to block three served for monitoring conditions for both blocks. For the main station, monitoring equipment was mounted on a $18.5 \mathrm{~m}$ aluminum lattice tower and included propeller anemometer triads (Gill UVW, R.M. Young, Traverse City, MI) and air temperature sensors (thermistors, YSI, Yellow Springs, $\mathrm{OH}$ ) at heights of 3.1, 9.2 and $18.5 \mathrm{~m}$ above ground level, as well as a humidity sensor (capacitance hygrometer, Heath $\mathrm{Co}$. Benton Harbour, $\mathrm{MI})$ at a height of $18.5 \mathrm{~m}$. Electrical signals from these instru- 


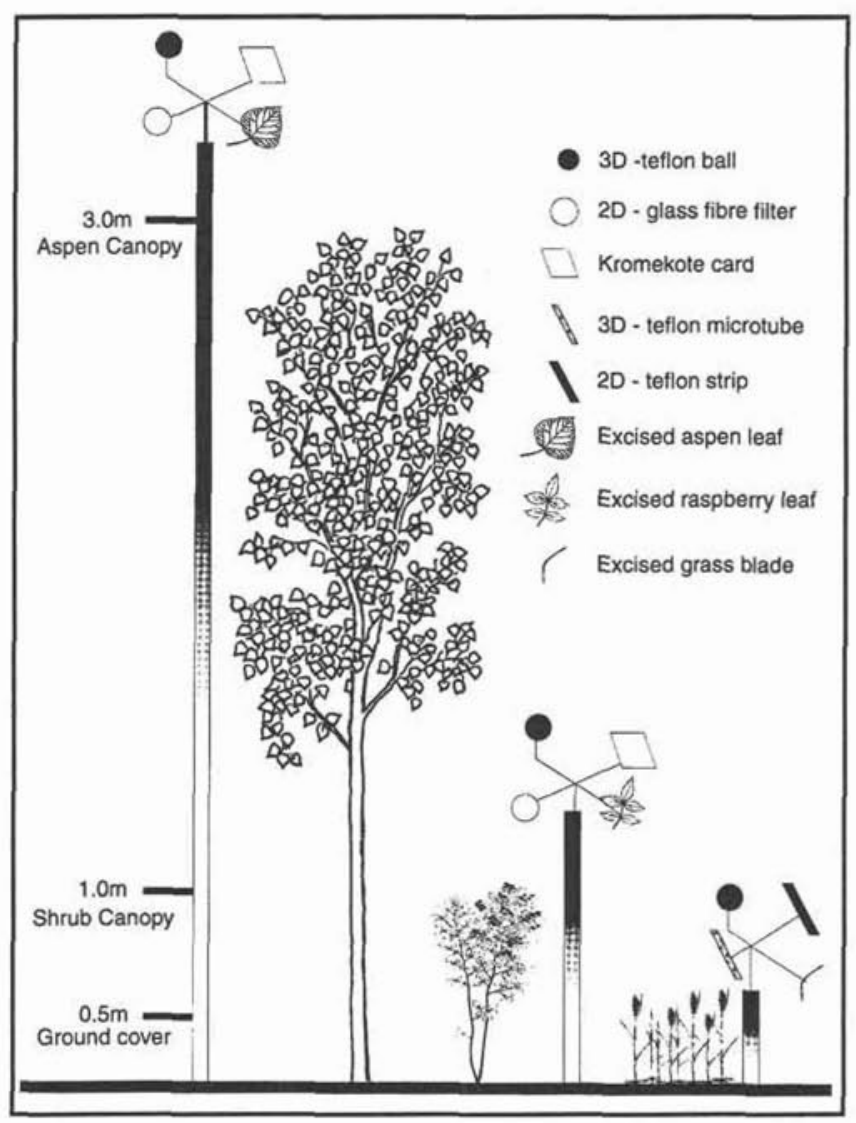

Fig. 2. Schematic representation of collector arrays established at three heights in relation to the tree, shrub and ground-cover vegetative tiers.

ments were sampled instantaneously at frequency of $0.2 \mathrm{~Hz}$ and averaged over successive $10 \mathrm{~min}$ periods using a data acquisition system (Isaac 91, Cyborg, Newton, MA). At blocks one and two, additional stations were established using $9.2 \mathrm{~m}$ towers instrumented with a vane-mounted anemometer (R.M. Young, Traverse City,MI) at $9.2 \mathrm{~m}$, three air temperature sensors (Campbell Scientific, Edmonton, ALB.) at heights of 9.2, 4.6 and $2.3 \mathrm{~m}$, as well as a relative humidity sensor (Campbell Scientific, Edmonton, $A B$ ) at a height of $4.6 \mathrm{~m}$. Signals were logged at a frequency of $1 \mathrm{~Hz}$ using a CR10 datalogger (Campbell Scientific, Edmonton, $\mathrm{AB}$ ).

\section{Herbicide Application}

A Bell 206B helicopter, equipped with a SIMPLEX ${ }^{\circledR}$ boom and 30 TEEJET ${ }^{\circledR}$ D8-46 nozzles, calibrated to deliver a volume application rate of $35 \mathrm{~L} \mathrm{ha}^{-1}$, was used for all applications. The track spacing was planned to be $20 \mathrm{~m}$ and the spray was released at $10 \mathrm{~m}$ above the target canopy. Glyphosate $\left(V_{i s i o n}{ }^{\circledR}\right)$ and triclopyr (Release ${ }^{\circledR}$ ) herbicides were applied at nominal rates of 1.5 and $1.9 \mathrm{~kg}$ a.e. $\mathrm{ha}^{-1}$ respectively during morning and evening spray sessions of 16 August 1993. Erio acid red $(0.1 \% \mathrm{w} / \mathrm{v})$ dye was added to spray mixtures to facilitate assessment of drop-size spectra. Prior to chemical applications, a few residual trees were felled on all plots in Block one and the triclopyr plots in blocks two and three to allow for uniform spray release height. No other attempts were made to alter the non-uniform shape and size of plots or their proximity to mature timber stands.
Table 2. Aircraft and associated specifications for application of herbicide treatments.

\begin{tabular}{ll}
\hline Parameter & Specification \\
\hline Contractor & Zimmer Air Services Inc. \\
Pilot & Mr. Paul Zimmer \\
Aircraft & Bell 206B; Registration \#CG-FEC \\
Rotor length & $10.2 \mathrm{~m}$ \\
Dispersal system & Simplex Hydraulic Boom \\
Boom length & $10.9 \mathrm{~m}$ \\
Nozzles & Teejet (30 evenly spaced within $8.18 \mathrm{~m}$ \\
& of boom length) \\
Nozzle orientation & $90^{\circ}$ (straight down) \\
Tips \& swirlplates & D $8-46$ (all new immediately prior to \\
& experiment) \\
Swath width & $20 \mathrm{~m}$ \\
Track spacing & $20 \mathrm{~m}$ \\
Release height & $10 \mathrm{~m}$ above canopy \\
Air speed & $44 \mathrm{~km} \mathrm{~h}^{-1}$ \\
Average load capacity & $375 \mathrm{~L}$ \\
Avg. calibrated VMD & $535.2 \mu \mathrm{m}$ \\
Avg. calibrated NMD & $204.82 \mu \mathrm{m}$ \\
Avg. calibrated density & $7.2 \mathrm{drops} \mathrm{cm}^{-2}$ \\
Avg. calibrated coverage & $3.5 \%$ of Kcard surface area \\
Calibrated volume rate & $35 \mathrm{~L} \mathrm{~min}{ }^{-1}$ \\
\hline
\end{tabular}

Details of the aircraft specifications and calibration, as conducted on site at 18:00 h 16 August 1993 are provided (Table 2). Aircraft calibration tests were conducted in an open area adjacent to block three, and involved over spraying, at a release height of $10 \mathrm{~m}$, a series of 40 Kromekote cards placed along a tertiary logging road and spaced at $2.0 \mathrm{~m}$ intervals. Cards were set out in a straight line perpendicular to the aircraft flight line. Atmospheric conditions at the time of the calibration test were characterized as average wind speed of $1.22 \mathrm{~m} \mathrm{~s}^{-1}$, from $215^{\circ}$, an average air temperature of $18.0^{\circ} \mathrm{C}$ and an average relative humidity of $75.7 \%$. Resulting dropsize spectra were measured on the interior 20 cards having visible spray deposit using both an automated card reader (SWATHKIT ${ }^{\circledR}$ ) and following general microscopic methods as described below.

\section{Deposit Quantification}

All deposit collectors were recovered from the field within four to six h post-application, placed in labeled containers, and stored frozen until processed. Care was taken to minimize dislodging of deposits during sampler collection by handling collectors with small stainless steel tweezers or by direct transfer into the containers using the alligator clips. To avoid potential sorptive losses of triclopyr butoxyethyl ester, all samples from triclopyr treated plots were placed in glass or Teflon containers; glyphosate samples were stored in plastic containers.

Deposits of glyphosate free acid and triclopyr butoxyethyl ester were quantified for each collector using either high performance liquid chromatographic (HPLC) or gas liquid chromatographic (GLC) techniques respectively (Thompson et al. 1989; Thompson et al. 1995). Triclopyr ester residues were converted to acid equivalents based upon the mass ratio of the two compounds. Specifics of the analytical methods are provided (Table 3). Analytical results were converted to amount of active ingredient per unit area of the collection surface $(\mu \mathrm{g}$ $\mathrm{cm}^{-2}$ ) and normalized by calculating deposit of active ingredient as a percentage of the nominal application rate for each compound. Analytical methods were validated prior to experiment initiation and a concurrent quality control $(\mathrm{QC})$ program 


\begin{tabular}{|c|c|c|}
\hline Specification & Glyphosate method & Triclopyr method \\
\hline $\begin{array}{l}\text { Chromatographic } \\
\text { System } \\
\text { Detector } \\
\text { Autosampler } \\
\text { Injection technique } \\
\text { Final sample volume }\end{array}$ & $\begin{array}{l}\text { HPLC } \\
\text { Varian } 5560 \\
\text { UV-200@ } 570 \mathrm{~nm} \\
\text { Varian } 8085 \\
\mathrm{n} / \mathrm{a} \\
10 \mathrm{~mL} \text { mobile phase }\end{array}$ & $\begin{array}{l}\text { GLC } \\
\text { Varian Vista } 6000 \\
{ }^{63} \mathrm{Ni} \text { Electron Capture } \\
\text { Varian } 8000 \\
\text { Hot on-column } \\
10 \mathrm{~mL} \text { iso-octane }\end{array}$ \\
\hline Injection volume & $100 \mu \mathrm{L}$ & $2 \mu \mathrm{L}$ \\
\hline Column type & $\begin{array}{l}\text { Aminex A-9 } \\
(10 \mathrm{~cm} \times 4.6 \mathrm{~mm} \text { i.d. })\end{array}$ & $\begin{array}{l}\text { DB-5 } 0.25 \mu \mathrm{m} \text { film } \\
(30 \mathrm{~m} \times 0.25 \mu \mathrm{m} \text { i.d. })\end{array}$ \\
\hline Mobile phase & $\begin{array}{l}0.005 \mathrm{KH}_{2} \mathrm{PO}_{4}(\mathrm{pH}=1.9) \\
\text { with } 4 \% \text { methanol } \\
0.55 \mathrm{~mL} \mathrm{~min} \text { min }^{-1}\end{array}$ & Nitrogen $1+29 \mathrm{~mL} \mathrm{~min}^{-1}$ \\
\hline $\begin{array}{l}\text { Operating temperatures } \\
\text { Injector } \\
\text { Column } \\
\text { Detector } \\
\text { Post-column reactor }\end{array}$ & $\begin{array}{l}\mathrm{n} / \mathrm{a} \\
50^{\circ} \mathrm{C} \\
\mathrm{n} / \mathrm{a} \\
135^{\circ} \mathrm{C}\end{array}$ & $\begin{array}{l}200^{\circ} \mathrm{C} \\
85-250 @ 30^{\circ} \mathrm{C} \mathrm{min}^{-1} \\
325^{\circ} \mathrm{C} \\
\mathrm{n} / \mathrm{a}\end{array}$ \\
\hline Derivatization & 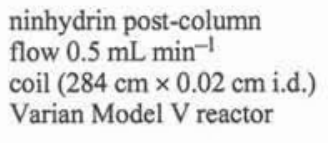 & $\begin{array}{l}\text { methylation @ } 95^{\circ} \mathrm{C} \\
\left(14 \% \mathrm{BF}_{3} \text { in methanol) }\right.\end{array}$ \\
\hline Retention time & $7.1 \mathrm{~min}$ & $11.44 \mathrm{~min}$ \\
\hline Detector linearity & $100-2500 \mathrm{ng}$ injected & $10-40 \mu \mathrm{g}$ injected \\
\hline $\begin{array}{l}\text { Limit of detection } \\
\text { natural \& artificial matrices }\end{array}$ & $0.10 \mu \mathrm{g} \mathrm{g}^{-1}$ & $0.02 \mu \mathrm{g} \mathrm{g}^{-1}$ \\
\hline $\begin{array}{l}\text { Validated limits of } \\
\text { quantification } \\
\text { natural matrix } \\
\text { artificial matrix }\end{array}$ & $\begin{array}{l}0.5 \mu \mathrm{g} \mathrm{g}^{-1} \\
2.0 \mu \mathrm{gcm}^{-2}\end{array}$ & $\begin{array}{l}0.1 \mu \mathrm{g} \mathrm{g}^{-1} \\
0.025 \mu \mathrm{g} \mathrm{cm}^{-2}\end{array}$ \\
\hline
\end{tabular}

was run throughout the duration of field sample analyses. The QC program involved duplicate blank matrices fortified at various levels of active ingredient, equilibrated for a minimum of $18 \mathrm{~h}$ under cold, dark conditions. Duplicate QC samples were analyzed simultaneously with each set of field samples. For each collection surface, mean recovery efficiency, standard deviation and coefficient of variation were calculated. Means from the QC data were used to correct raw field deposit data for analytical recovery efficiency. Additionally, quality assurance samples involving all collector types, fortified at levels equivalent to the nominal application rate for each herbicide, were deployed and left exposed for $4 \mathrm{~h}$ to environmental conditions extant on block one. The field quality assurance (QA) samples ( $n=3$ per collector type/herbicide treatment combination) were collected, transported and stored under conditions identical to those for actual field deposit samples. Thus QA sample analyses allowed assessment of potential degradative losses for herbicide active ingredients between the time of deposition and time of analysis.

Results for analytical QC and QA samples are presented (Table 4). Results of the laboratory $Q C$ program were highly consistent with preliminary validation studies and demonstrated excellent recovery efficiency $(>76 \%)$ and precision $(<6.5 \% \mathrm{CV})$ for all analyte/matrix combinations. Recovery efficiency for glyphosate analyses were essentially quantitative and thus correction for analytical losses was unnecessary. For the tri- clopyr ester analyte, recovery efficiency ranged from 76 to $82 \%$ depending upon the matrix and thus appropriate factors (Table 4) were applied to correct raw deposit data for analytical recovery efficiency. Mean recovery efficiencies observed for field QA samples were similar to those for laboratory QC samples indicating no significant degradative losses for these analytes under the conditions of sampling, transport and storage employed.

\section{Assessment of Dropsize Spectra}

Kromekote cards $(5 \times 5 \mathrm{~cm})$ were deployed to enable drop-size spectra and density assessment. Kromekote cards were labeled on the underside and placed in individual plastic petri-dishes by block and treatment. Drop-size spectra were determined by optical analysis of stains following the general recommendations of Sundaram et al. (1993). Drop densities (drops $\mathrm{cm}^{-2}$ ) were measured in five one $\mathrm{cm}^{2}$ areas card ${ }^{-1}$ using a binocular microscope at $12 \times$ magnification and sized using $50 \times$ magnification and an eyepiece equipped with a graticule. Volume median diameter (VMD), volume average diameter (VAD), number median diameter (NMD) and the diameters at the 10th and 90th percentiles of the distribution $\left(\mathrm{DV}_{0.1}\right.$ and $\mathrm{DV}_{0.9}$ respectively) were calculated for each sample using an empirically determined spread factor of 2.5 (Payne 1993). In a number of cases, drop-size spectra and density could not be determined owing to the deleterious effects of dew on stain shape and visibility. 


\begin{tabular}{|c|c|c|c|c|c|c|c|}
\hline $\begin{array}{l}\text { Collector } \\
\text { type }\end{array}$ & Analyte & $\begin{array}{c}\text { Fortification } \\
\text { rate equiv. } \\
\left.(\mu \mathrm{g} \mathrm{cm})^{-2}\right)\end{array}$ & $n$ & $\begin{array}{c}\text { Mean } \\
\text { rec.(\%) }\end{array}$ & STDS & CV & CF \\
\hline \multicolumn{8}{|c|}{ Laboratory quality control sample results } \\
\hline \multirow[t]{2}{*}{ 2D } & Triclopyr & $20-30$ & 11 & 82.19 & 3.33 & 4.05 & 1.22 \\
\hline & Glyphosate & 19 & 5 & 99.61 & 2.39 & 2.40 & 1.00 \\
\hline \multirow[t]{2}{*}{ 3D } & Triclopyr & 14.6 & 23 & 80.32 & 5.03 & 6.26 & 1.25 \\
\hline & Glyphosate & 14.7 & 12 & 99.14 & 2.82 & 2.85 & 1.01 \\
\hline \multirow[t]{2}{*}{ FO(aspen) } & Triclopyr & 34.5 & 12 & 76.4 & 3.82 & 5.00 & 1.32 \\
\hline & Glyphosate & & 6 & 99.74 & 2.25 & 2.25 & 1.00 \\
\hline \multicolumn{8}{|c|}{ Field quality assurance sample results } \\
\hline \multirow[t]{2}{*}{$2 \mathrm{D}$} & Triclopyr & 19 & 3 & 82.61 & 5.51 & 6.66 & \\
\hline & Glyphosate & 15 & 3 & 93.33 & 4.57 & 4.89 & \\
\hline \multirow[t]{2}{*}{ 3D } & Triclopyr & 19 & 3 & 78.02 & 12.65 & 16.21 & \\
\hline & Tlyphosate & 15 & 3 & 87.09 & 5.49 & 6.30 & \\
\hline \multirow[t]{2}{*}{$\mathrm{FO}$ (aspen) } & Triclopyr & 19 & 3 & 83.86 & 2.68 & 3.20 & \\
\hline & Glyphosate & 15 & 3 & 94.9 & 0.78 & 0.82 & \\
\hline
\end{tabular}

Note: STDS = sample standard deviation; $C V=$ coefficient of variation; $C F=$ correction factor applied to correct field residue data for analytical recovery; $2 \mathrm{D}=2$-dimensional artificial collector, Whitman \#1 glass fibre filter paper surface area $38.48 \mathrm{~cm}^{2} ; 3 \mathrm{D}=3$-dimensional artificial collector, Teflon ball with surface area $45.34 \mathrm{~cm}^{2} ; F O=$ excised natural aspen foliage aspen, surface area $\left.(\mathrm{n}=40) 19 \pm 4 \mathrm{~cm}^{2}\right)$.

\section{Statistical Analysis}

For the purposes of spray deposit assessment, each plot was considered as a unique combination of site and meteorological conditions. Accordingly, a completely randomized design (CRD) was used for subsequent analysis, with two treatments (triclopyr or glyphosate), each applied to four replicate spray plots. The statistical model employed to examine differences in mean on-target deposit was:

$$
Y_{\mathrm{ijk}}=\mu+H_{\mathrm{i}}+P_{\mathrm{j}(\mathrm{i})}+S_{\mathrm{k}(\mathrm{ijk})}
$$

where $Y_{\mathrm{ijk}}=$ deposit observed on the $k$ th sample in the $j$ th plot of the $i$ th herbicide treatment $\mu=$ overall mean, $H_{\mathrm{i}}=$ the fixed effect associated with the $i$ th herbicide $(i=1,2), P_{\mathrm{j}(\mathrm{i})}=$ the random effect of the $j$ th plot within the $i$ th herbicide treatment, $S_{\mathrm{k}(\mathrm{ijk})}=$ the random effect of the $k$ th sampler within plot $j$ and herbicide $i$.

To meet the assumptions of this model, variances of the data from each plot were checked for normality and subjected to Bartlet's test for homogeneity of variance. Residuals were also examined for normality and signs of heteroscedasticity.

Within each spray plot, 12 SS locations were established as described above. Deposit data resulting from the six SS locations corresponding to the overall mean LAI value were used to investigate deposit under constant canopy density, while data from all SS locations were regressed with corresponding LAI measurements to examine the functional relationship between deposit and the immediately surrounding target canopy density. As there was no relationship between LAI and on-target deposit for any of the eight spray plots $(P=0.746$ for glyphosate, 0.233 for triclopyr) data for all over-sprayed SS locations were pooled for assessment of mean on-target deposit.

To examine the vertical distribution of herbicide deposit, the general model was employed in a repeated-measures multivariate analysis of variance (RM-MANOVA). This permitted the testing of differences between the deposits on the
3D collectors deployed at each of the three collection levels. Each observation in the above model was considered as a trivariate response representing the deposit at each of the three levels. The assumptions for this analysis are that the deposit values in the model have a multivariate normal distribution with a common covariance matrix across treatments. In this experiment, simple correlation and a parallel RM-ANOVA analysis was conducted to examine the relationship between deposits on excised natural foliage, $2 \mathrm{D}$ and $3 \mathrm{D}$ artificial collectors. Further, each observation in the model was considered as a multivariate response representing the deposit measured by each collector type at a particular level.

\section{Results and Discussion}

Meteorological Conditions During Herbicide Applications

Meteorological conditions during the periods of herbicide applications are provided (Table 1). All applications were completed during early morning or late evening spray sessions on 16 August 1993, with the time required to treat an individual plot being 10 minutes or less. The meteorological data were incomplete owing to equipment malfunction. However the data set suggested generally similar conditions at all sites and thus conditions at block three are reported. Meteorological conditions were typical for operational silvicultural herbicide applications, with moderate windspeeds $\left(<2.8 \mathrm{~m} \mathrm{~s}^{-1}\right.$ at 18.5 $\mathrm{m})$, stable atmospheric boundary layers, moderate air temperatures $\left(12.8<\mathrm{T}<15.3^{\circ} \mathrm{C}\right)$ and high relative humidities $(89-98 \%)$ in all cases.

\section{Droplet Density and Spectral Assessment}

Droplet densities on Kromekote cards deployed at the three sampling heights for each subsampling station were determined, and mean values at each sampling height, for each treatment plot, are presented (Table 5). Droplet densities at the upper sampling height suggested greater coverage $\left(22\right.$ drops $\left.\mathrm{cm}^{-2}\right)$ for glyphosate treatments as compared to triclopyr treatments ( 15 drops $\left.\mathrm{cm}^{-2}\right)$. In both cases, substantial canopy 
Table 5. Drop density and spectra of impinging spray cloud by sampling height

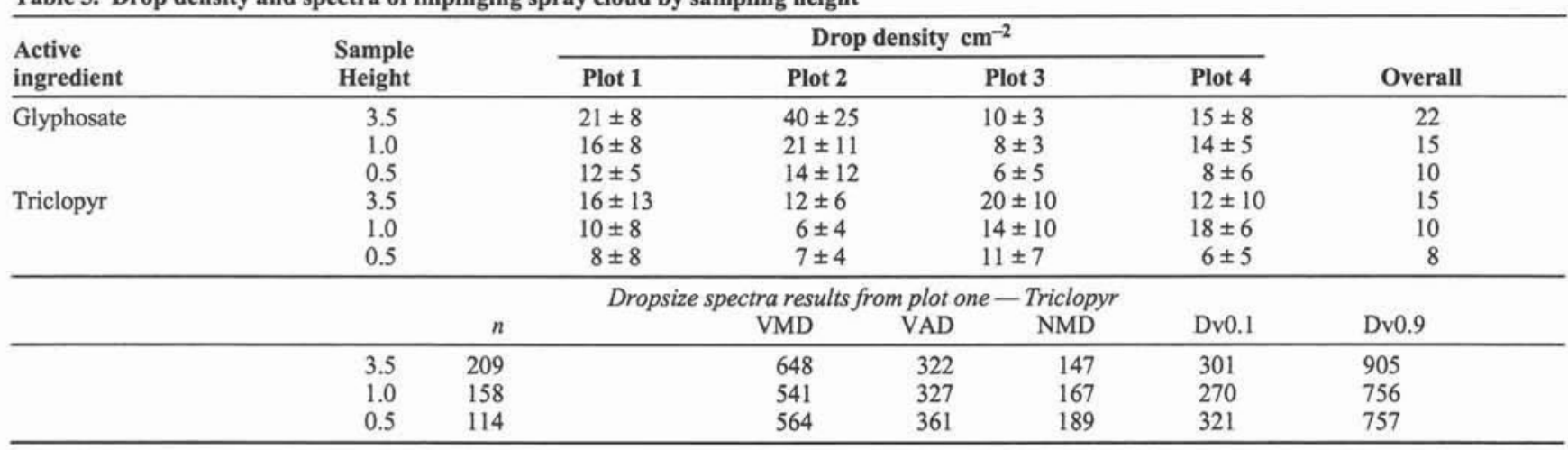

penetration was observed with droplet densities at the $0.5 \mathrm{~m}$ and $1.0 \mathrm{~m}$ ranging from $45-53 \%$ and $66-68 \%$ of those at the $3.5 \mathrm{~m}$ level for glyphosate and triclopyr treatments respectively. A strong predominance of droplets on the upper-side of the cards was observed at all heights, suggesting that under the conditions of this study, characterized by a stable atmospheric boundary layer, impingement of small droplets associated with the horizontal component of mass flux (Duan et al. 1994) was relatively unimportant. Spectral assessment of many Kromekote cards was obviated by dew deposition which caused distortion of droplet stains in some cases and differential surface properties of cards in other cases, thereby negating accurate assessment of stain sizes. Such problems are commonly encountered in field studies employing Kromekote cards (Teske et al. 1994). Droplet spectra observed for the triclopyr application to block one, where no dew effect occurred, are presented (Table 5) as an example of spectral differences for the impinging spray cloud relative to sampling height. The dropsize data were analyzed by a $\chi^{2}$ test (Volk 1980) and found to be non-homogeneous $(P<0.05)$, indicating significant differences between the dropsize spectra at different heights above ground. Larger VMD and $\mathrm{DV}_{0.9}$ were observed near the top of the canopy as compared to lower sampling heights, indicating that the largest drops impinged within the target canopy as has been observed previously (MacNichol 1996)

\section{On-target Deposit}

Due to operational factors, all glyphosate applications were made prior to triclopyr applications. During the morning spray session, wind gusts began to exceed regulatory limits ( $2.2 \mathrm{~m} \mathrm{~s}^{-1}$ at spray release height) for operational spraying between 9:30 and 10:00 am, forcing a delay in triclopyr application to plots two and three until late in the evening $(21: 00 \mathrm{~h})$ when winds had again diminished to levels consistently below regulatory thresholds $\left(2.2 \mathrm{~m} \mathrm{~s}^{-1}\right.$ at spray release height) (Table 1). As such, the marginally significant differences $(P=0.053)$ in overall deposit means at the top of the aspen canopy (Table 6) were expected and are primarily a function of different meteorological conditions rather than inherent formulation characteristics. As a result, only within-treatment comparisons are of relevance here. Further, drop density on Kromekote cards, quantification of active ingredient on all sampler types, and post-application aerial photography, all confirmed that occasional strips were left untreated due to inappropriate swath positioning. Such errors,
Table 6. Analysis of variance for on-target deposit ${ }^{1}$ of glyphosate and triclopyr herbicides

\begin{tabular}{lllll}
\hline Source & d.f. & SS & F & P>F \\
\hline Between herbicides & 1 & $4,598.94$ & 3.86 & 0.053 \\
Plots (within herbicides) & 6 & $22,344.63$ & 3.12 & 0.009 \\
Plots (within glyphosate) & $(3)$ & $8,915.71$ & 2.49 & 0.066 \\
Plots (within triclopyr) & $(3)$ & $13,428.92$ & 3.75 & 0.014 \\
$\begin{array}{l}\text { Samples } \\
\text { (within plots (within herbicides)) }\end{array}$ & 78 & $93,023.97$ & & \\
Total & 85 & $119,967.54$ & & \\
\hline
\end{tabular}

${ }^{1}$ data for deposit to 2-D artificial collectors (glass fibre filter papers) at 3.5 $\mathrm{m}$ sampling height $\mathrm{p}$ (normality for plots (within herbicides): $>0.196 \mathrm{p}$ (homogeneity of variance): 0.630 .

common to aerial application of forest pesticides (Barry 1977; Richardson et al. 1993) may have been exacerbated in these trials owing to the combined effects of small spray block sizes ( 4.9 to $10.4 \mathrm{ha}$ ), proximity of standing timber or other no-spray zones, and notable topographical relief. Therefore reported deposit data are for subsampling locations that were clearly over sprayed (subsamples varying from 9-12 depending upon treatment and plot, $n=43$ for both treatments) and exclude those subsampling stations which clearly did not receive any deposit.

Overall mean deposit (mean $\pm \mathrm{SE}$ ) of glyphosate and triclopyr on aspen foliage equated to $68.45 \pm 6.13$ and $50.28 \pm$ $6.01 \%$ of the nominal application rates $\left(1.5\right.$ and $1.9 \mathrm{~kg} \mathrm{ha}^{-1}$ respectively) (Fig. 3). While the overall mean foliar deposits were not significantly $(P=0.747)$ different from those derived from $2 \mathrm{D}$ artificial collection surfaces $(71.20 \pm 5.34 \%$ and 56.06 $\pm 5.31 \%$ ) when averaged across treatments, there were statistically significant differences $(P<0.05)$ between foliar deposit and $2 \mathrm{D}$ estimates when data were considered within a given treatment. Thus, the average on-target deposit estimates and variability observed in this study depended on the type of collection surface employed (see following detailed comparison of collectors). Overall, on-target deposit averages estimated from natural foliage or $2 \mathrm{D}$ collector results were similar to those in previous studies using similar spray equipment on small spray blocks (Newton et al. 1990; Thompson et al. 1992). The graphical presentation (Fig. 3) emphasizes the degree of variation in mean deposit among plots within both treatments. Although such differences were only marginally significant 


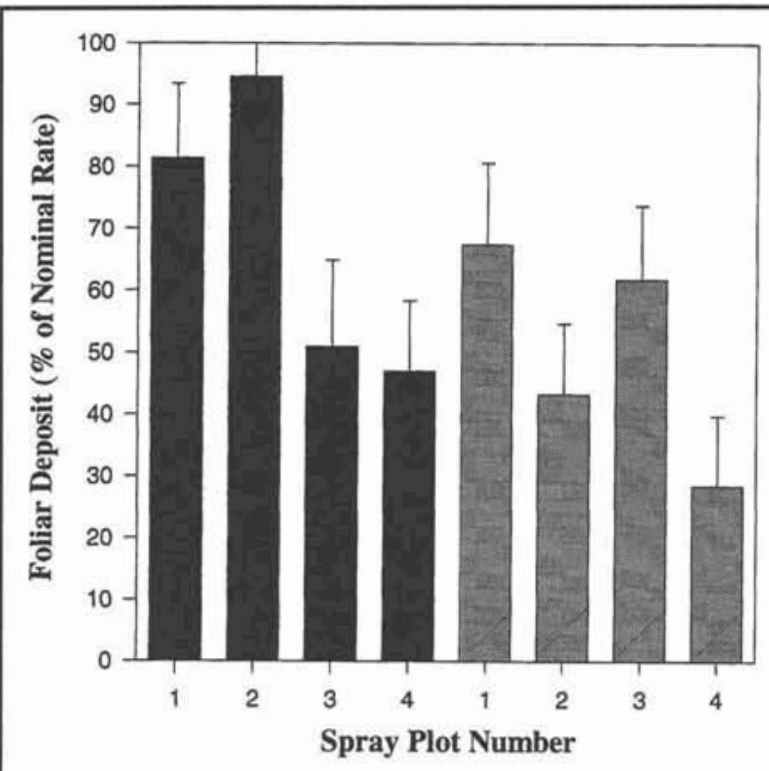

Glyphosate

Triclopyr

Fig. 3. Mean deposit of glyphosate and triclopyr herbicides (Vision ${ }^{\circledR}$, Release $\left.{ }^{\otimes}\right)$ on excised aspen foliage held at $3.5 \mathrm{~m}$ above ground level in $(n=4)$ spray plots. (Values are least squares means \pm standard errors).

for glyphosate treatments $(P=0.066)$, they were highly significant for triclopyr treatments $(P=0.014)$ (Table 6). The ratio of variances for plots versus samples $(F=3.12$, Table 6$)$ indicates that variation between plots was greater than variation within plots and suggests that meteorological, operational, and/or site conditions which differ for each plot had a strong influence on deposit. For glyphosate treatments, the lowest mean foliar deposits were observed on plots three and four (Fig. 3) for which higher windspeeds were recorded (Table 1). In the former case, lowest deposits for individual sample locations were observed in the northwest corner of the plot where boom times were very short and efforts to protect the integrity of other treatment plots resulted in poor deposit near plot boundaries. In fact, the three sub-sample locations on transect I of this plot (Fig. 1) showed only trace deposits and were omitted from statistical analysis and mean calculations. In the case of glyphosate treatment, plot four, flight lines were oriented East-West along the contours of the steep slope on the southern portion of the plot. Based on subsequent aerial photography, the low observed deposits (locations H7 \& I7) resulted from inappropriate swath placement.

For triclopyr treatments to plots two and three, wind speeds and other meteorological conditions were very similar during applications (Table 1) yet foliar deposit varied markedly, with lower mean deposit ( $43.43 \pm 11.44 \%$ of nominal rate) on plot two which was characterized by proximal standing timber on the northern, eastern and western boundaries (Fig. 1). In comparison, higher mean deposits $(67.40 \pm 13.21 ; 65.45 \pm$ 12.54) were observed on plots 1 and 3 , respectively, where flight lines were not impaired by standing timber. On triclopyr spray plot four, lowest deposits were observed at locations E2 and F2, closest to the northern edge of the plot bounded by standing timber and may be attributed to either insufficient upwind

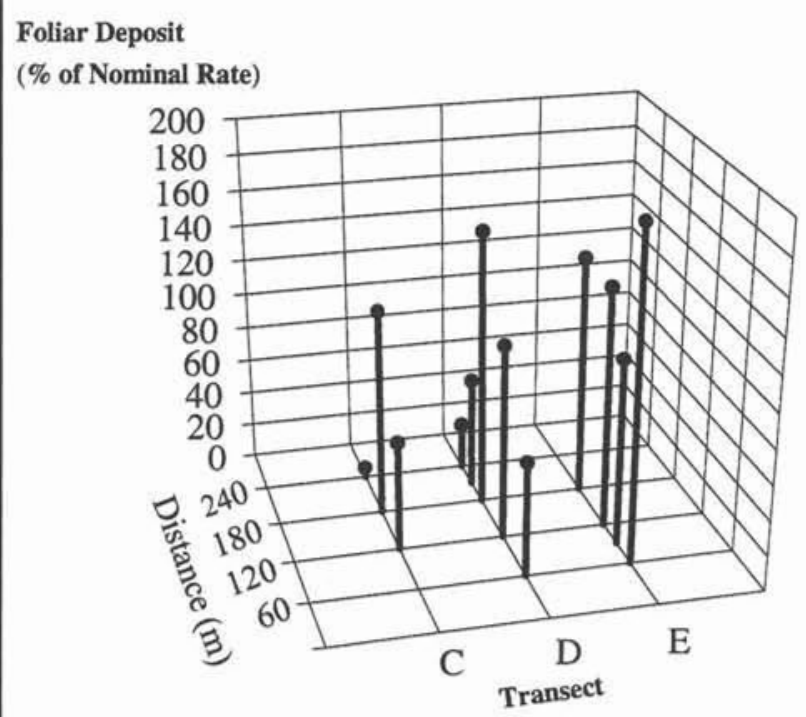

Fig. 4. Distribution of glyphosate deposit on excised aspen foliage held at $3.5 \mathrm{~m}$ above ground level for each of 11 sub-sampling stations on spray plot two; flight path parallel to sampling transect lines and perpendicular to wind direction (from $268^{\circ}$ or L-R on diagram). (Values are least squares means \pm standard errors).

offset of the initial spray swath or higher than optimal spray release height resulting from the need to fly above proximal standing timber. The degree of within plot variation which may occur under these experimental conditions is shown for glyphosate plot two (Fig. 4). The data demonstrate the typical pattern of least deposit at sampling locations nearest the upwind side or at the extremes of sampling transects running parallel to the flight lines. In this case, a good mean deposit $(94.55 \pm 11.94)$ was achieved, largely owing to high deposition on samplers located on the downwind and mid portions of the plot.

Given that meteorological conditions for spray plots were generally similar, these results suggest that differences in operational parameters (e.g. swath offset and overlap, release height, spraying speed) induced by difficult site conditions (proximity of standing timber, steep terrain, irregular spray boundaries) may have contributed substantially to overall spray deposit variation. Newton et al. (1990) also noted highest variability in deposit associated with treatments where aircraft followed contours of steep side slopes or flew up and down steep gradients. While instantaneous release height and spraying speed were not monitored in this experiment, these results appear to generally support the findings of Teske and Barry (1993a) who identified release height, spraying speed, wind direction and wind speed as critical operational factors controlling deposit based on parametric sensitivity tests using the FSCBG aerial application computer model (Teske and Barry 1993b).

\section{Vertical Distribution of Foliar Deposits}

Vertical distribution of herbicide deposits through the tiered vegetative canopy was assessed using RM-MANOVA of deposits on both excised foliage and on the 3D artificial collector. Both analyses demonstrated no significant differences 


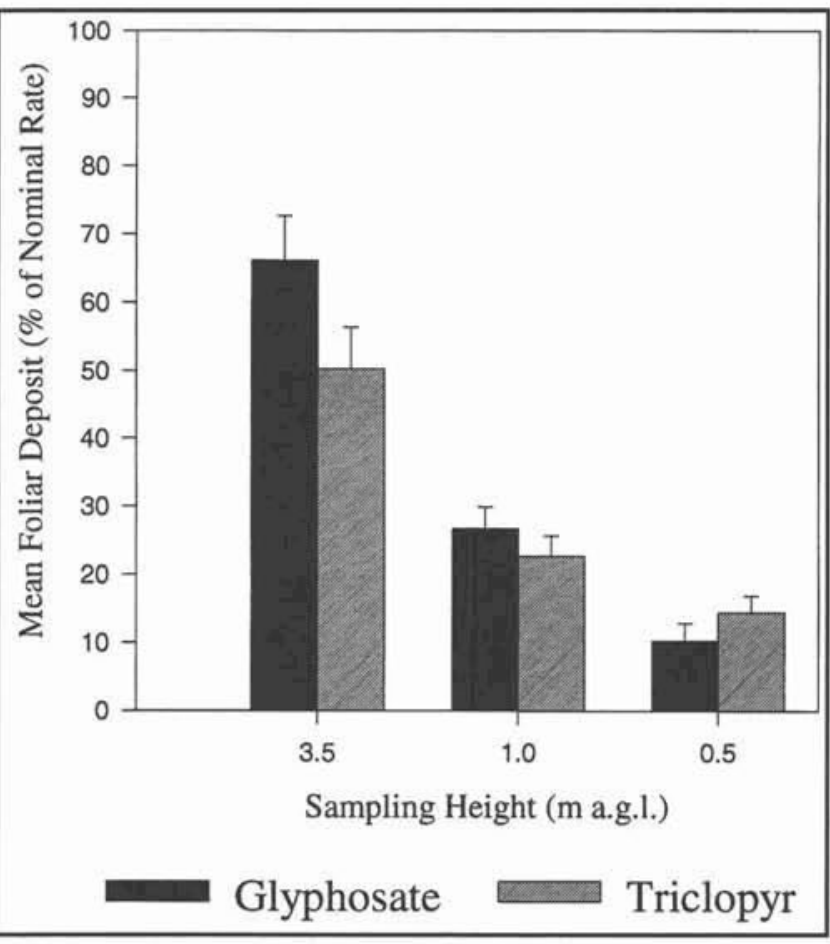

Fig. 5. Vertical distribution of foliar deposits of glyphosate and triclopyr herbicides on excised aspen, raspberry and grass foliage held at $3.5,1.0$ and $0.5 \mathrm{~m}$ sampling heights respectively. (Values are least squares means \pm standard errors.)

in the distribution pattern among the two herbicide treatments ( $P=0.245$ and $P=0.534$ respectively) and a significant degree of variability between plots within a given herbicide $(P<0.012)$. Most importantly, both analyses demonstrated highly significant differences in deposit estimates in relation to sampling height $(P<0.001)$. Overall mean foliar deposit for each treatment and sampling level are presented (Fig. 5), showing a consistent trend in both treatments, with substantially lower deposit at the herbaceous and ground levels as compared to those in the aspen canopy. Results for triclopyr plot three, where similar deposits at the 3.5 and $1.0 \mathrm{~m}$ levels were observed, represent the singular exception to this general trend.

The high proportion of deposit intercepted by the target canopy are consistent with findings of previous studies (Rafferty et al. 1981; Newton et al. 1990; Barry 1984). Our results demonstrate that on average, low-shrub and ground-cover vegetation received less than $25 \%$ and $12 \%$ respectively of the nominal application rate for the herbicide treatments, demonstrating the point made by the latter authors that upper tiers of a vegetative canopy can protect lower layers from receiving a phytotoxic dose. The results are consistent with the concept of canopy penetration as a progressive removal of airborne drops incident from above by deposition through sedimentation and inertial impaction. While substantially lower deposits to herbaceous and ground-cover vegetation may have beneficial effects in terms of reduced potential for direct or indirect effects on wildlife, it may be detrimental to efficacy in cases where herbaceous and graminaceous competition is equivalent or greater than that resulting from competitive hardwood tree species. This effect may be an important consideration given previous studies which have documented the potential for decreasing nominal rates of glyphosate without a significant reduction in efficacy (Nova Scotia Department of Lands and Forests 1989; Pitt et al. 1993). Although herbicide rates may be reduced without compromising efficacy in single-layer competitor scenarios, or where species in the complex are all quite susceptible, this may not be the case in tiered canopies where tree species may intercept the majority of the spray cloud, impairing efficacy on herbaceous or ground-competitors and necessitating re-treatment to achieve effective conifer release.

Comparison of Deposit on Foliage and Artificial Collectors

The inconsistencies in observed deposit estimates for collectors deployed at each sampling height are illustrated (Fig. 6). Comparison of histogram bars at the $3.5 \mathrm{~m}$ sampling height demonstrate reasonable agreement between deposit on 2D collectors and excised aspen foliage for both glyphosate and triclopyr treatments as evidenced by the simple correlation coefficients ( $r=0.62$ and 0.74 respectively). However, this trend was not always consistent among plots within each treatment, as evidenced by significant differences $(P=0.004$ for glyphosate, $P=0.05$ for triclopyr) detected for comparisons of deposit on 2D collectors and excised aspen foliage. At the $3.5 \mathrm{~m}$ sampling height, the $3 \mathrm{D}$ collectors underestimated both foliar and 2D collector deposits for glyphosate treatments, but gave essentially equivalent estimates to both natural and 2D artificial collectors for triclopyr treatments (Table 7, Fig. 6). In contrast, the 3D collectors tended to overestimate deposits on excised natural foliage for both compounds at the $1.0 \mathrm{~m}$ sampling height, but to a lesser degree than the artificial 2D collectors in most cases. The lack of consistency in these relationships suggest substantive differences in catch efficiencies of the various collectors in relation to sampling height. Such differences may reflect complex interactions between the physical/chemical properties of the formulations or active ingredients, surface conditions of the collector and micro meteorological conditions induced by the canopy, all of which in turn control size and trajectory of droplets, degree of adherence to the collector, as well as wind speed and direction at the specific point of sampling. For example, the low bias observed for 3D collectors and glyphosate treatments at the $3.5 \mathrm{~m}$ height may reflect a lower potential for retention of larger droplets on rounded surfaces, particularly for highly water soluble compounds and where the surface has been moistened by dew, as was the case for at least some of the spray blocks. Conversely, in the case of triclopyr treatments, where the ester form of the compound is less water soluble and dew was not a factor, deposit estimates from 3D collectors at the $3.5 \mathrm{~m}$ sampling height exceeded those on natural foliage in three of four cases.

These results conflict somewhat with the findings of other researchers who have demonstrated relatively higher collection efficiencies for 3D as compared to 2D artificial collectors on both a theoretical and empirical basis (Richardson et al. 1989; Miller et al. 1992; Duan et al. 1994). The difference in results may be partially explained by the relatively large droplet spectrum $\left(\mathrm{VMD}=648 \mu \mathrm{m}\right.$ and size range $\mathrm{DV}_{0.1}$ to $\mathrm{DV}_{0.90}=$ 301 to $905 \mu \mathrm{m}$ ) in this study as compared to previous studies (VMD=282 [Richardson et al. 1989] size range $<500 \mu \mathrm{m}$ [Miller et al. 1992; Duan et al. 1994]) and by the softer, rougher and more sorptive surface characteristics of glass fibre filter papers used as $2 \mathrm{D}$ collectors in this study as compared to 


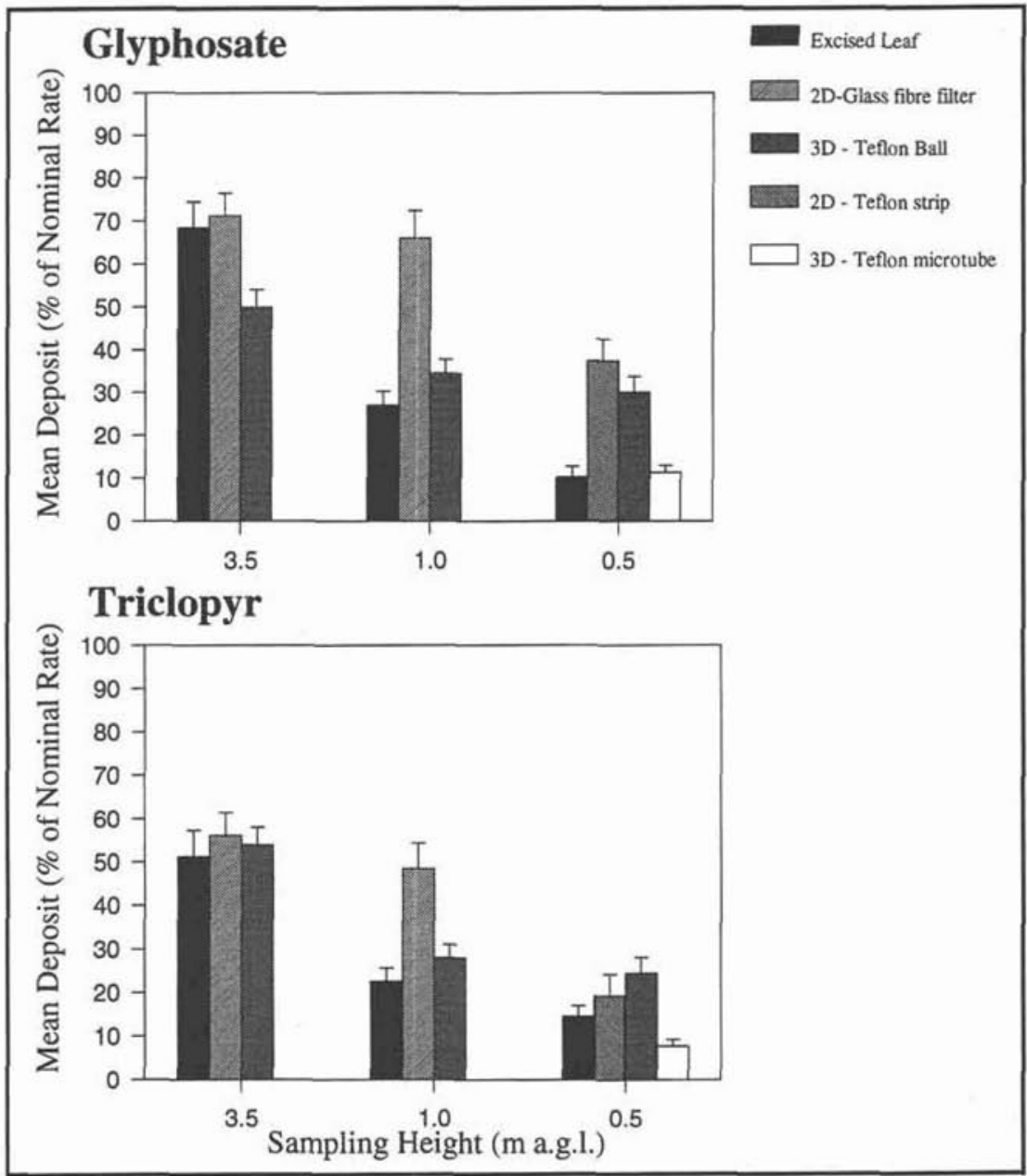

Fig. 6. Comparison of glyphosate and triclopyr deposits on various artificial surfaces and excised foliage by sampling height. (Values are least squares means \pm standard errors.)

\begin{tabular}{|c|c|c|c|c|c|}
\hline \multirow{2}{*}{ Treatment } & \multicolumn{2}{|c|}{ Sample collector } & \multirow{2}{*}{$\begin{array}{c}\text { Least } \\
\text { squares mean }\end{array}$} & \multirow{2}{*}{ SE } & \multirow{2}{*}{$\begin{array}{l}\text { Corr. } \\
\text { coeff. }\end{array}$} \\
\hline & Height & Type & & & \\
\hline \multirow[t]{3}{*}{ Glyphosate } & 3.5 & $\begin{array}{l}\text { FO } \\
2 \mathrm{D} \\
3 \mathrm{D}\end{array}$ & $\begin{array}{l}68.45 \\
71.20 \\
49.84\end{array}$ & $\begin{array}{l}6.13 \\
5.34 \\
4.15\end{array}$ & $\begin{array}{l}\overline{0.62} \\
0.63\end{array}$ \\
\hline & 1.0 & $\begin{array}{l}\text { FO } \\
2 \mathrm{D} \\
3 \mathrm{D}\end{array}$ & $\begin{array}{l}27.01 \\
66.02 \\
34.46\end{array}$ & $\begin{array}{l}3.24 \\
6.38 \\
3.34\end{array}$ & $\begin{array}{l}\overline{0.53} \\
0.51\end{array}$ \\
\hline & 0.5 & $\begin{array}{l}\text { FO } \\
\text { 2Dts } \\
\text { 3D } \\
\text { 3Dmt }\end{array}$ & $\begin{array}{l}10.22 \\
37.38 \\
28.98 \\
11.29\end{array}$ & $\begin{array}{l}2.48 \\
5.13 \\
3.71 \\
1.63\end{array}$ & $\begin{array}{l}- \\
0.49 \\
0.78 \\
0.60\end{array}$ \\
\hline \multirow[t]{3}{*}{ Triclopyr } & 3.5 & $\begin{array}{l}\text { FO } \\
2 \mathrm{D} \\
3 \mathrm{D}\end{array}$ & $\begin{array}{l}51.17 \\
56.06 \\
53.83\end{array}$ & $\begin{array}{l}6.09 \\
5.31 \\
4.12\end{array}$ & $\begin{array}{l}\overline{0} \\
0.62\end{array}$ \\
\hline & 1.0 & $\begin{array}{l}\text { FO } \\
2 \mathrm{D} \\
3 \mathrm{D}\end{array}$ & $\begin{array}{l}22.59 \\
48.44 \\
27.94\end{array}$ & $\begin{array}{l}2.99 \\
5.90 \\
3.08\end{array}$ & $\begin{array}{l}\overline{0.22} \\
0.41\end{array}$ \\
\hline & 0.5 & $\begin{array}{l}\text { FO } \\
\text { 2Dts } \\
\text { 3D } \\
\text { 3Dmt }\end{array}$ & $\begin{array}{r}14.60 \\
19.21 \\
24.42 \\
7.69\end{array}$ & $\begin{array}{l}2.41 \\
4.98 \\
3.61 \\
1.58\end{array}$ & $\begin{array}{l}\overline{0} \\
0.60 \\
0.58\end{array}$ \\
\hline
\end{tabular}

Where: FO= excised natural foliage (aspen@3.5, red raspberry@1.0 m and grass@0.5 m);2D=2-dimensional artificial collector, Whitman \#1 glass fibre filter paper $11 \mathrm{~cm}$ diam.; 2Dts=2-dimensional Teflon strip; 3D =3-dimensional artificial collector, Teflon ball; 3Dmt =3-dimensional artificial collector, Teflon microtube. 
Kromekote cards, mylar or acetate sheets and/or glass plates as used in previous studies. Based on the published theory and empirical evidence, 3D collectors were expected to have relatively higher deposit than artificial 2D collectors, particularly at the $3.5 \mathrm{~m}$ sampling height where the capture efficiency of $2 \mathrm{D}$ collectors would be theoretically minimized (Duan et al. 1994). However, based on the mean deposits $(n=4)$ for both glyphosate and triclopyr herbicide treatments in this study, deposits on spherical Teflon balls (3D collectors) were either equivalent to or less than those on glass fibre filter papers (2D collectors) at both 3.5 and $1.0 \mathrm{~m}$ sampling heights (Table 7 and Fig. 6). At the $0.5 \mathrm{~m}$ sampling height neither $3 \mathrm{D}$ collectors (Teflon ball or Teflon microtube) provided consistently higher deposits than artificial 2D collectors (Teflon strips) designed to mimic excised grass blades (Fig. 6).

In practical terms, none of the artificial collectors employed in this study provided deposit estimates which were consistently highly correlated $(r>0.60)$ (Table 7), or statistically $(P$ $>0.05$ ) equivalent, with proximally located natural excised foliage held at the same sampling height. Thus, based on the results of intensive sampling for this semi-operational experiment, we are in agreement with the general conclusion of Richardson et al. (1989) who stated "...for information on deposition on the target, usually foliage, there is no substitute for sampling the target itself".

\section{Conclusions}

Results of this experiment demonstrate overall mean deposition (mean $\pm \mathrm{SE}$ ) of glyphosate and triclopyr on target aspen foliage equating to $68.45 \pm 6.13$ and $50.28 \pm 6.01 \%$ of the nominal application rates $\left(1.5\right.$ and $\left.1.9 \mathrm{~kg} \mathrm{ha}^{-1}\right)$ respectively. A high degree of variation in deposit both within and between plots indicated that variation in operational parameters (e.g. release height, spraying speed) as influenced by local site factors (e.g. proximity of standing timber, topographical relief) can be important determinants in uniformity and accuracy of herbicide deposit. A consistent, significant $(P<0.001)$ trend in the deposit profile through tiered vegetative canopies was observed with highest impingement ( $>50 \%$ of the nominal application rate) in the aspen canopy and approximately $25 \%$ and $12 \%$ in the low-shrub and ground-cover tiers, respectively. Deposit comparisons showed that none of the artificial collectors tested were consistently effective at estimating the foliar deposit on proximally held excised natural foliage.

\section{Acknowledgments}

The authors thank staff of the Ontario Ministry of Natural Resources (OMNR) - Eldon Kangas and staff(Doug Stojkovic, Jamie Burton, Morris Massicotte, Nick Dryhorub) of the Thunder Bay office for control of spray operations, and John Winters (Sault Ste. Marie, OFRI) for contractual arrangements and coordination of field activities. We are particularly indebted to David Thomas, Linda MacDonald, Art Robinson, (Canadian Forest Service, Sault Ste. Marie) and Heather Barnes, Larry Jones, Wade Pritchard, Tim Cooey, and Diana Vajdik. (OMNR, Thunder Bay) for extended hours spent in field sampling. Thanks also to David Curry and Anthony Battel (Canadian Forest Service, Sault Ste. Marie) for assistance in meteorological monitoring. Finally, we are grateful to DowElanco Canada and Monsanto Canada for supply of herbicide products and to Paul Zimmer and Jason Evans of
Zimmer Air Services Co. for spray applications. Financial support for this project was provided by the Ontario Ministry of Natural Resources Vegetation Management Alternatives Program (VMAP) and by the Canadian Forest Service Natural Resources Canada.

\section{References}

Barry, J.W. 1977. Problems associated with maintaining consistent swaths when spraying forests with helicopters. Agricultural Aviation 18: 18-22.

Barry, J.W. 1984. Deposition of Chemical and Biological Agents in Conifers. Chapter 10, pp. 117-137. In: Chemical and biological controls in forestry. W.Y. Garner and J.H. Harvey Jr. (eds.). ACS Symposium Series \#238. American Chemical Society, Washington, DC. 406 p.

Bell, F.W., R.A. Lautenschlager, R.G. Wagner, D.G. Pitt, J.W. Hawkins, and K.R. Ride 1997. Motor-manual, mechanical and herbicide release affect early successional vegetation in northwestern Ontario. For. Chron. 73: 61-68.

Campbell, R.A. and C.A. Howard. 1993. Priorities for forestry herbicide application technology research. Can. J. For. Res. 23: 22042212.

Cariton, J.B. and L.F. Bouse. 1987. Exploring aerial spray sampling with a cylindrical collector. Amer. Soc. Agric. Eng. Paper No. 871070. St. Joseph, MI.

Duan, B., K. Mierzejewski and S. Maczuga. 1994. Efficiency of deposition of pesticide droplets on flat cards and spheres. J. Environ. Sci. Health. B29: 1153-1167.

Lautenschlager, R.A., F.W. Bell, R.G. Wagner and J.A. Winters. 1997. The Fallingsnow Ecosystem Project: Comparing conifer release alternatives in northwestern Ontario. For. Chron. 73: 35-38. LI-COR 1991. LAI 2000 Plant Canopy Analyzer Instruction Manual. LI-COR Incorporated. Lincoln Nebraska.

MacNichol, A.Z. 1996. Canopy penetration in almond orchards - Part 2. FSCBG simulation of drop deposition and downwind drift. United States Department of Agriculture - Forest Service. Report \#FHTET 96-03. February 1996. 52 p.

Miller, D.R., W.E. Yendol and M.L. McManus. 1992. On the field sampling of pesticide spray distribution using Teflon spheres and flat cards. J. Environ. Sci. and Health. B27: 185-208.

Newton, M., F. Roberts, A. Allen, B. Kelpsas, D. White and P. Boyd. 1990. Deposition and dissipation of three herbicides in foliage, litter and soil of brushfields of Southwest Oregon. J. Agric. Food Chem. 38: 574-583.

Nova Scotia Department of Lands and Forests. 1989. Controlling competing vegetation with lower than recommended rates of glyphosate: a comparison of two trial. Nova Scotia Department of Lands and Forests. Truro Res. Rep. 18.

Payne, N.J. 1993. Spray dispersal from aerial silvicultural glyphosate applications. Crop Protection. 12: 463-469.

Payne, N.J. and D.G. Thompson. 1992. Off-target glyphosate deposits from aerial applications under various meteorological conditions. Pestic. Sci. 34: 53-59.

Payne, N.J., J.C. Feng and P.E. Reynolds. 1990. Off-target deposits and buffer zones required around water for aerial glyphosate applications. Pestic. Sci. 30: 183-198.

Picot, J.J.C., D.D. Kistmanson, R.E. Mickle, R.B.B. Dickison, C.M. Riley and C.J. Wiesner. 1993. Measurements of foliar and ground deposits in forestry aerial spraying. American Society of Agricultural Engineers 36: 1013-1024.

Pitt, D.G., D.G. Thompson, N.J. Payne and E.G. Kettela. 1993. Response of woody eastern Canadian forest weeds to fall foliar treatments of glyphosate and triclopyr herbicides. Can. J. For. Res. 23: 2490-2498.

Rafferty, J.E., R.K. Dumbauld, H.W. Flake Jr., J.S. Barry and J. Wong. 1981. Comparison of modeled and measured deposition for the Withlacoochee Spray Trials. Report 81-3. USDA Forest 
Service Forest Pest Management Application Group: Davis, CA. Riley, C.M., C.J. Wiesner and W.A. Sexsmith. 1991. Estimating off-target spray deposition on the ground following aerial application of glyphosate for conifer release in New Brunswick. J. Environ. Sci. and Health. B26: 185-208.

Richardson, B., J. Ray and A. Vanner. 1989. Evaluation of techniques to measure aerial spray deposition. Proceedings of the $42 \mathrm{nd}$ N.Z. Weed and Pest Control Conference. pp. 95-99.

Richardson, B., J. Ray and A. Vanner. 1990. Factors affecting spray deposition following the aerial application of herbicides. Proceedings of the 9th Australian Weeds Conference. Adelaide, South Australia. August, 1990.

Richardson, B., J. Ray and A. Vanner. 1993. Quantification of herbicide spray deposit variation following aerial application in forestry operations. Proceedings of the 46th N.Z. Plant Protection Conference. 319-324.

Sundaram, A., K.M.S. Sundaram, J.S. Zhu, R. Nott, J. Curry and J.W. Leung. 1993. Spread factor, penetration depth and stain height of drops of aqueous pesticide mixes on Kromekote cards. Journal of Environmental Science and Health B28: 243-273.

Teske, M.E. and J.W. Barry. 1993a. Parametric sensitivity in aerial application. American Society of Agricultural Engineers. 36: 27-33.
Teske, M.E. and J.W. Barry. 1993b. FSCBG: an aerial spray dispersion model for predicting the fate of released material behind aircraft. Environmental Toxicology and Chemistry. 12: 453-464.

Teske, M.E., A.Z. MacNichol and J.W. Barry. 1994. USDA Forest Service Spread Factor Technology Database. In: Pesticide formulations and application systems: 14th Volume. F.R. Hall, P.D. Berger and H.M. Collins (eds). American Society for Testing and Materials, Philadelphia.

Thompson, D., J. Cowell, R. Daniels, B. Staznik and L. MacDonald. 1989. Liquid chromatographic method for quantitation of glyphosate and metabolite residues in organic and mineral soils, stream sediments and hardwood foliage. J. Assoc. Off. Anal. Chem. 72: 355-360.

Thompson, D.G., D.G. Pitt, R.A. Fleming and E.G. Kettela. 1992. Glyphosate efficacy on eastern Canadian forest weeds. Part I: Experimental design and on-target deposit. Can. J. For. Res. 22: 1151-1159.

Thompson, D.G., D.G. Pitt, T. Buscarini, B. Staznik, D.R. Thomas and E. Kettela. 1995. Initial deposits and persistence of forest herbicide residues in sugar maple (Acer saccharum) foliage. Can. J. For Res. 24: 2251-2262.

Volk, W. 1980. Applied statistics for engineers. R.E. Krieger Publishing Co. Huntington, New York. 415 p. 